\title{
On the Application of Computer Science and Technology in Computer Education
}

\author{
Haoran Ou \\ The Houde Academy, Shenzhen 518134, Guangdong, China \\ Email: 83684886@qq.com
}

\begin{abstract}
The computer has become an indispensable and important tool in people's daily life and work. It brings more convenience to people and provides important conditions for human survival and development. Therefore, the application of computer science and technology to computer education can enable students to have a correct understanding of computer application concepts and practical operations, thereby improving the level of computer education. This article mainly analyzes the advantages and significance of the application of computer science and technology in computer education, and proposes the measures to be used, hoping to provide certain references and suggestions for the cultivation of computer talents.
\end{abstract}

Keywords: computer science and technology, computer education, application

The use of computer science and technology in computer education can not only help students have a correct understanding of computer education, but also help improve the level of computer education, thereby training more computer professionals for the society.

\section{The role of computer science and technology in computer education}

At present, computer science and technology have been integrated with computer education, which has helped the smooth development of computer education. Its application in computer education mainly has the following three aspects ${ }^{[1]}$. First, the application of computer science and technology ensures the smooth development of basic computer education. It can be used as an auxiliary tool to help solve various technical problems in basic computer education, and to visually display computer professional knowledge for students, so as to ensure the smooth development of basic education. Second, the application of computer science and technology can help improve students' learning efficiency. Students can use computer science technology to study and practice professional knowledge in their spare time. Computer science technology increases the opportunities for students to learn about computer expertise, guarantees students' study time, and improves the efficiency of computer learning. Third, the application of computer science and technology has improved students' learning ability. Students can use computer science and technology to consolidate their learning content in their spare time, and continue to understand the application process and production process of the computer through the actual operation of the computer. Computer science and technology have improved students' learning efficiency and provided more guarantees for the smooth development of computer education.

\section{Advantages of using computer science and technology in computer education}

\subsection{Conducive to maintaining teacher-student relationship}

Computer education has become one of the important subjects of college education in our country. Through the teaching of theoretical knowledge and practical knowledge, it can continuously improve students' computer operation ability and provide guarantee for students to participate in work after graduation. However, in the actual education process, improper communication between teachers and students will affect the smooth development of computer education and is not conducive to students' learning and mastering professional knowledge. The application of computer science and technology provides more ways for teachers and students to communicate. It breaks the limitations of communication between teachers and students, not only provides more convenience for students to learn professional knowledge, but also helps to ease the relationship between teachers and students, thereby improving the effect of computer education ${ }^{[2]}$.

\subsection{Conducive to the development of study habits}

The application of computer science and technology in computer education has broken the traditional model of computer education, innovated the content and form of computer education, and stimulated students' interest in computer 
learning. Teachers can continuously guide students to develop good habits of independent learning by expanding teaching content, thereby laying a good foundation for students to learn and use computer knowledge.

\subsection{Conducive to broadening educational horizons}

The application of computer science and technology in computer education has innovated the model of computer education, combining practical teaching with theoretical teaching. On the basis of students learning computer theory knowledge, lead students to practice theoretical knowledge. This not only improves students' understanding and application ability of knowledge, but also helps students gain in-depth understanding of computer science and technology and helps students expand their professional knowledge.

\subsection{Conducive to reducing education costs}

The application of computer science education contributes to the diversified development of computer education. Teachers can use computer science and technology to transform the teaching form of professional knowledge. This can not only enhance the interest of professional teaching and stimulate the enthusiasm of students to learn professional knowledge, but also change the form of assessment. For example, the online assessment method is used to conduct computer professional assessment. This can save educational costs and improve the efficiency of the use of educational resources.

\section{Specific measures to use computer science and technology in computer education}

\subsection{Innovate in technological application}

Colleges and universities can combine the needs of computer education to innovate technology application models. Improving the computer education system is conducive to the continuous improvement of computer professional education. In the process of using computer science and technology, teachers can combine the needs of professional teaching to improve the content and form of professional education. On the one hand, teachers can make online courseware to provide more learning resources for students to learn professional knowledge, increase students' learning channels, and improve students' learning effects. On the other hand, teachers can combine the needs of computer education and computer science and technology to enrich educational content and increase the interest of professional teaching. This can not only stimulate students' interest in learning computers, but also help students learn professional knowledge in depth and continuously improve their computer skills.

\subsection{Improve teaching facilities}

Computer education is different from the education of other subjects. It needs to use teaching facilities to carry out the actual test of theoretical teaching so as to improve students' computer operation level. Therefore, the application of computer science and technology can help improve teaching facilities and provide more guarantees for the smooth development of computer education ${ }^{[3]}$. On the one hand, computer science and technology can be used to analyze the problems in computer practice education, provide basic guarantee for students to perform computer practice operations, and contribute to the continuous improvement of computer education. On the other hand, computer science and technology can assist teachers in comprehensively analyzing students' professional learning conditions, summarizing students' problems in computer professional learning, and doing a good job of data recording. It can provide more accurate data for teachers to make professional evaluation of students. Computer science and technology can not only help students fully grasp their own problems in professional learning, provide guidance and suggestions for students, but also provide guarantee for teaching auxiliary work, thereby improving the teaching level of computer majors.

\subsection{Enrich teaching methods}

The application of computer science and technology in computer education provides more ways to enrich teaching methods, helps the scientific use of teaching resources, and improves the teaching level of computer majors. On the one hand, teachers can adopt interactive teaching methods and use computer science technology to rationally apply teaching resources. In the teaching of computer majors, computer science and technology can continuously deepen students' cognition and mastery of computer professional knowledge and help improve students' computer professional level. On the other hand, the interactive teaching method is proposed to achieve a perfect integration of theoretical teaching and practical teaching. The interactive teaching method can guide students to conduct practical operation tests on the basis of improving the students' theoretical knowledge of computer science, improve their mastery of computer knowledge, and provide assistance for students to study computer knowledge in depth. It helps the smooth development of computer education. 


\subsection{Apply distance education}

The application of computer science and technology has increased the ways of computer education. Long-distance education provides a platform for students to learn computer expertise, breaks the limitations of learning, and helps students improve their professional learning level. For example, teachers can design distance education courseware based on the needs of computer majors, center on the knowledge in computer textbooks, and use online teaching resources to use pictures, videos, audio, etc. to make fun design of distance education content. This allows students to learn professional knowledge through distance education courseware and improve their learning efficiency. At the same time, teachers can also use distance education to design students' after-school learning content and plan key knowledge for students. This can not only help students organize the review content scientifically, but also help students improve their computer knowledge system and improve their computer professional level.

\subsection{Build the hypermedia classroom}

With the continuous integration of computer science technology and computer education, in the actual teaching process, teachers can combine professional teaching needs and students' learning needs to innovate in teaching methods. On the basis of ensuring the professional teaching level, continue to guide students to learn computer knowledge in depth. This will not only increase the students' computer professional knowledge reserves, but also provide more support for students to use computers for operation and design. For example, teachers can build hypermedia classrooms with the help of computer science technology. It perfectly integrates computer professional teaching knowledge and network teaching information, and improves the vividness of computer classroom education. Hypermedia classrooms display computer expertise in a dynamic way to help students understand computer expertise in depth. This will not only help increase students' computer knowledge reserves, but also help create a good classroom teaching atmosphere, guide students to explore professional knowledge and develop good study habits. The proposal and application of hypermedia classrooms have changed the learning status of students in traditional computer classroom teaching, played the guiding and educational role of the classroom, and contributed to the continuous improvement of students' professional knowledge and professional ability ${ }^{[4]}$.

\section{Conclusion}

To sum up, the application of computer science and technology in computer education helps to improve the application technology, teaching facilities and educational methods of computer education. On the basis of improving the teaching level of computer science, it mobilizes students' interest in computer learning. Improved students' professional knowledge level and professional ability, so that students become high-quality talents with both knowledge and ability.

\section{References}

[1] Li Xiaosong, Zhou Kun. Research on the application of computer science and technology in computer education in colleges and universities. Computer Products and Circulation. 2020; (11): 6.

[2] Yang Shaobin. Discussion on the application of computer science and technology in computer education. Basic Education Curriculum Reform Research Center of the Ministry of Education. Proceedings of the 2020 "Basic Education Reform and Innovation in the Internet Environment". Basic Education of the Ministry of Education Curriculum Reform Research Center; 2020: 179.

[3] Zhang Zhijun. Application of Computer Science and Technology in Computer Education. Science and Technology Wind. 2020; (17): 131.

[4] Wang Chuntian. Application of Computer Science and Technology in Computer Education. Talent. 2020 ; (11): 247. 